J. Perinat. Med. 15 (1987) 545

\title{
Fetal blood flow in diabetic pregnancy
}

\author{
Per Olofsson¹, Göran Lingman², Karel Marsál², and Nils-Otto Sjöberg ${ }^{1}$ \\ Departments of Obstetrics and Gynecology in Lund $^{1}$ and Malmö ${ }^{2}$, University of \\ Lund, Sweden
}

\section{Introduction}

The combined pulsed Doppler and real-time ultrasound technique enables non-invasive measurement of the fetal blood flow [2,5]. It can be used in evaluating fetal blood circulation, which may be valuable especially in high-risk pregnancies. Circulatory changes, as detected by Doppler ultrasound technique, often precede abnormalities of the fetal heart rate (FHR) pattern, as subsequently detected by electronic FHR monitoring $[12,14]$.

Reports on fetal blood flow measurements in diabetic pregnancy are sparse. KIRKINEN \& JoUPPILA [13] recorded umbilical venous flow and VISSER et al. [25] umbilical arterial flow velocity, but they found no abnormalities specific to diabetic pregnancy. In contrast, GiLL et al. [6] recorded a high volume blood flow in the umbilical vein.

The present study of a consecutive series of pregnant diabetic women was undertaken to ascertain whether any relationship existed between fetal blood flow and clinical variables in diabetic pregnancy.

\section{Material and methods}

Fetal blood circulation was examined in 40 consecutive diabetic pregnancies during the third trimester. Gestational age was determined in all pregnancies by ultrasonic biparietal diameter measurement in the 17 th postmenstrual week. Twenty-one women were delivered in Lund and 19 in Malmö. Mean maternal age was 29.2 years (range 19-39). Nineteen women were primiparous. According to a modified White classification

\section{Curriculum vitae}

Per OlofsSon, M.D., Ph.D., B. A., was born in 1948 in Malmö, Sweden. He graduated from the University of Lund with a Bachelor's Degree in Mathematics in 1969, and with a Medical Degree in 1975. Following residency training at the County Hospital of Ängelholm, he joined the Department of

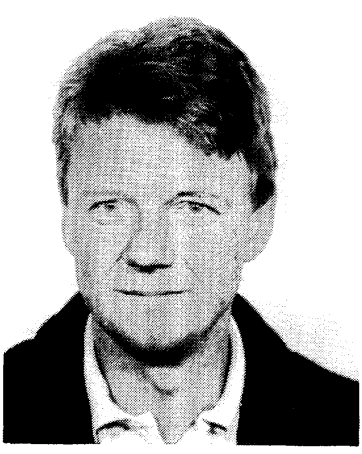
Obstetrics and Gynecology, University of Lund, in 1981. He defended a thesis on diabetic pregnancy management for the Degree of Doctor of Medicine in 1986. His main interest is in the field of perinatal medicine.

[20] three women belonged to class A (all gestational diabetes), 10 to class $\mathrm{AB}$ (6 gestational diabetes), 5 to class $\mathrm{B}, 12$ to class $\mathrm{C}, 5$ to class $\mathrm{D}$, and 5 to class $F$.

Diabetic control included checks of glycosylated hemoglobin $\left(\mathrm{HbA}_{1 \mathrm{c}}\right)$ every $2-3$ weeks, values within mean and $2 \mathrm{SD}$ of the general population being considered normal. On this basis, 25 women $(62.5 \%)$ were satisfactorily regulated during the third trimester.

Coincident complications during the perinatal period are shown in table I. One of 11 women with hypertension had begun antihypertensive medication at the time of blood flow measurement.

Antenatal fetal supervision included electronic FHR monitorings, performed as nonstress tests 
Table I. Obstetrical and neonatal data on the 40 diabetic pregnancies and infants.

\begin{tabular}{|c|c|c|c|}
\hline & $\mathrm{n}$ & $\%$ & \\
\hline \multicolumn{4}{|l|}{ Pregnancy complications } \\
\hline Hypertension & 11 & 27.5 & $\begin{array}{l}3 \text { cases of essential } \\
\text { hypertension }\end{array}$ \\
\hline \multicolumn{4}{|l|}{ Labor and delivery } \\
\hline Ominous FHR pattern & 5 & 16.7 & 10 cases not monitored \\
\hline Low fetal scalp blood $\mathrm{pH}$ & 4 & - & obtained in 12 cases \\
\hline Low cord blood $\mathrm{pH}$ & 8 & 27.6 & obtained in 29 cases \\
\hline Apgar score $<7$ at $1 \mathrm{~min}$ & 5 & 12.5 & \\
\hline $5 \min$ & 2 & 5.0 & \\
\hline $10 \mathrm{~min}$ & 1 & 2.5 & \\
\hline Fetal distress ${ }^{a}$ & 14 & 35.0 & \\
\hline Preterm delivery & 2 & 5.0 & $<37$ gestational weeks \\
\hline Post-term delivery & 1 & 2.5 & $>42$ gestational weeks \\
\hline Instrumental delivery & 4 & 10.0 & vacuum extraction or forceps \\
\hline Cesarean section & 12 & 30.0 & 7 elective sections \\
\hline \multicolumn{4}{|l|}{ Neonatal course } \\
\hline Large-for-gestational age ${ }^{b}$ & 8 & 20.0 & birth weight $>$ mean $+2 \mathrm{SD}$ \\
\hline Small-for-gestational age $\mathrm{b}$ & 0 & 0 & birth weight $<$ mean -2 SD \\
\hline Pulmonary maladaptation ${ }^{c}$ & 3. & 7.5 & \\
\hline Hypoglycemia & 1 & 2.5 & asymptomatic; < $1.7 \mathrm{mmol} / 1$ \\
\hline Hyperbilirubinemia & 5 & 12.5 & $>340 \mathrm{umol} / 1$ \\
\hline \multirow[t]{2}{*}{ Congenital malformation } & 1 & 2.5 & multiple anomalies \\
\hline & 0 & 0 & \\
\hline Perinatal mortality & 0 & 0 & \\
\hline
\end{tabular}

a Fetal distress implies any of the following: ominous fetal heart rate pattern in labor, low fetal scalp blood $\mathrm{pH}$, low cord blood $\mathrm{pH}$, or Apgar score $<7$.

b For reference, see [24].

c Synonymous to wet lung syndrome.

(NSTs). All women had a NST performed within one week before parturition. Altogether 670 NSTs (range 2-54 tests/woman) were performed. According to our classification system [19] 660 tests $(98.5 \%)$ were classified as normal, and eight women had pathological tests. No test was severly pathological.

The FHR was monitored electronically throughout labor. Fetal scalp blood $\mathrm{pH}$ was determined when indicated (12 cases). The umbilical cord was immediately clamped at birth and cord blood $\mathrm{pH}$ determined. Apgar scores were recorded at 1, 5 and $10 \mathrm{~min}$.

Fetal distress was defined as the occurrence of ominous intrapartum FHR patterns $[1,10]$, low fetal scalp blood $\mathrm{pH}(\leq .7 .25)$, low cord blood $\mathrm{pH}$ (arterial $\leq 7.15$, venous $\leq 7.20$ ), or low Apgar score $(<7)$.
Fetal blood flow was monitored with a $2 \mathrm{MHz}$ pulsed Doppler instrument (ALFRED, Vingmed A/S, Oslo, Norway) for blood velocity measurement, combined with a real-time linear array ultrasound scanner (ADR model 2130, Advanced Diagnostic Research Corp., Tempe, Arizona) for vessel imaging. The instrumental set-up and methodology are described in detail elsewhere [3]. All measurements were performed $1-2 \mathrm{~h}$ after meal and after at least $10 \mathrm{~min}$ rest. The women were placed in a semirecumbent position tilted slightly to the left.

Fetal blood velocity was recorded in: 1) the midpart of the descending thoracic aorta; 2) the abdominal aorta $1-2 \mathrm{~cm}$ above the bifurcation; 3 ) the intra-abdominal part of the umbilical vein; and 4) the umbilical arteries in the cord. Only recordings obtained during fetal inactivity and 


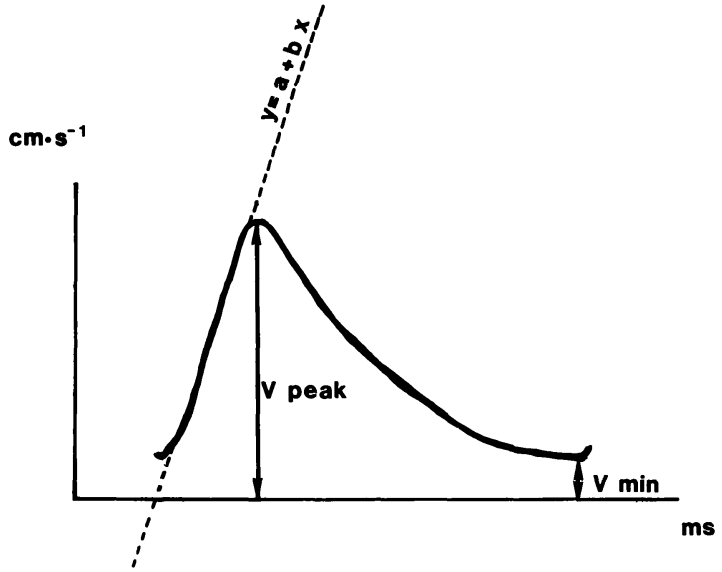

Figure 1. Schematical waveform analysis demonstrating peak velocity $\left(\mathrm{V}_{\text {peak }}\right)$, minimum velocity after the peak $\left(\mathrm{V}_{\min }\right)$, pulsatility index $\left(\left(\mathrm{V}_{\text {peak }}-\mathrm{V}_{\min }\right) / \mathrm{V}_{\text {mean }}\right)$, and rising slope $\left(b / V_{\text {mean }} ; b\right.$ is from the formula $\left.y=a+b x\right)$. $V_{\text {mean }}$ is the integrated mean velocity over the cycle.

apnoea were accepted for analysis. The results were not used for clinical guidance.

Mean blood velocity and vessel diameter measurements were used for calculating volume blood flow. The volume flow was related to fetal weight, as estimated from ultrasonic fetometry [23]. The waveform of the maximum blood velocity recorded in the aorta and umbilical artery was characterized by peak velocity, pulsatility index (PI) [8] and rising slope [18]. A schematic drawing demonstrating waveform analyses of these parameters is shown in figure 1.

A group of 21 healthy women with uncomplicated pregnancies was used as reference group (reference group A). These women were examined longitudinally with ultrasound Doppler measurements every second week during the third trimester [15, 16]. For comparison to the diabetic women, the alterations of those parameters progressively changing by gestational age (volume flow in all investigated vessels and PI in the umbilical artery) were considered.

Blood flow distribution within the fetus was estimated by expressing the flow in the abdominal aorta and umbilical vein, as proportions of the thoracic aorta flow. In the 25 cases where birth occurred within two weeks after the final measurement, umbilical venous flow was correlated to placental weight. A consecutive series of 100 non- diabetic women delivered at term was used for comparison of placental weight (mean weight $590.2 \mathrm{~g}, \mathrm{SD}$ 129.8) (reference group B).

Fetal blood flow was measured on three occasions during the third trimester: at 26-34 completed weeks (test I), at 35-37 weeks (test II), and between 38 weeks and delivery (test III). Six women had three measurements, 13 two measurements, and 21 only one measurement. In 18 cases the final measurement was performed within one week before parturition, in 25 within two weeks, and in 33 within three weeks.

Due to the sample size, the unpaired t-test was used for two-tailed statistical comparison between the diabetic and the reference group, and the Mann-Whitney U-test for comparison within the diabetic group. The linear correlation between umbilical venous volume blood flow and birth weight respectively placental weight was calculated.

\section{Results}

Blood flow measurements are given by test period in table II.

Thoracic descending aorta: The volume blood flow was consistently higher than in the reference group $A$, and markedly higher at test $I(p<0.01)$. At test II, the peak velocity was higher than in the reference group A $(p<0.05)$.

Abdominal aorta: The volume flow was increased at all three examinations $(\mathrm{p}<0.05)$. At test $\mathrm{I}$, the PI was lower than in the reference group A $(\mathrm{p}<0.01)$.

Umbilical artery: The PI in the umbilical artery was higher than the reference value (group A) at test III $(\mathrm{p}<0.05)$.

Umbilical vein: The volume blood flow was higher than in the reference group A at test $I(p<0.05)$, but normal at tests II and III.

Distribution of blood flow: Blood flow distribution in relation to gestational age is shown in figure 2. The volume flow in the thoracic descending aorta is given as $100 \%$. At test I (median gestational age 29 weeks), the placental proportion of the thoracic aortic flow was $51 \%$, decreasing to $45 \%$ at test II (median gestational age 36 weeks) and to $38 \%$ at test III. Corresponding proportions for viscera were $28 \%, 31 \%$ and $27 \%$, respectively; and for lower extremities, $21 \%, 24 \%$ and $35 \%$. 
Table II. Results of ultrasonic fetal blood flow measurements in pregnant diabetic women. Median gestational age was 29 weeks at test I, 36 weeks at test II, and 39 weeks at test III. Values are mean and SD.

\begin{tabular}{|c|c|c|c|c|c|}
\hline \multirow[b]{2}{*}{ Thoracic aorta } & $\begin{array}{l}\text { Test I } \\
(\mathrm{n}=17)\end{array}$ & $\begin{array}{l}\text { Test II } \\
(\mathrm{n}=26)\end{array}$ & $\begin{array}{l}\text { Test III } \\
(\mathrm{n}=22)\end{array}$ & \multicolumn{2}{|l|}{$\begin{array}{l}\text { Reference }^{\mathrm{a}} \\
(\mathrm{n}=21)\end{array}$} \\
\hline & & & & & \\
\hline $\begin{array}{l}\text { Mean velocity }(\mathrm{cm} / \mathrm{s}) \\
\text { Volume flow }(\mathrm{ml} / \mathrm{min} / \mathrm{kg})\end{array}$ & $\begin{aligned} 36.3 & \pm 5.7 \\
290.0 & \pm 68.6^{* *}\end{aligned}$ & $\begin{array}{r}35.8 \pm 6.4 \\
276.6 \pm 70.3\end{array}$ & $\begin{array}{r}31.4 \pm 5.9 \\
233.5 \pm 47.6\end{array}$ & $\begin{array}{r}34.6 \\
\text { I: } 232.2 \\
\text { II: } 257.2 \\
\text { III: } 221.0\end{array}$ & $\begin{array}{l} \pm 15.5 \\
\pm 50.5 \\
\pm 35.4 \\
\pm 41.4\end{array}$ \\
\hline $\begin{array}{l}\text { Peak velocity }(\mathrm{cm} / \mathrm{s}) \\
\text { Rising slope }(\mathrm{Hz}) \\
\text { Pulsatility index }\end{array}$ & $\begin{array}{c}118.3 \pm 24.0 \\
30.9 \pm 5.1 \\
1.90 \pm 0.29\end{array}$ & $\begin{array}{c}129.5 \pm 22.2^{*} \\
28.1 \pm 3.7 \\
1.90 \pm 0.27\end{array}$ & $\begin{array}{c}124.8 \pm 24.5 \\
30.2 \pm 7.7 \\
2.06 \pm 0.37\end{array}$ & $\begin{array}{c}115.6 \\
29.9 \\
1.96\end{array}$ & $\begin{array}{l} \pm 19.0 \\
\pm \quad 4.9 \\
\pm \quad 0.31\end{array}$ \\
\hline \multicolumn{6}{|l|}{ Abdominal aorta } \\
\hline $\begin{array}{l}\text { Mean velocity }(\mathrm{cm} / \mathrm{s}) \\
\text { Volume flow }(\mathrm{ml} / \mathrm{min} / \mathrm{kg})\end{array}$ & $\begin{array}{r}34.8 \pm 5.0 \\
197.7 \pm 40.0^{*}\end{array}$ & $\begin{array}{r}35.5 \pm 6.6 \\
189.8 \pm 43.3^{*}\end{array}$ & $\begin{array}{r}32.2 \pm 6.2 \\
155.6 \pm 31.3^{*}\end{array}$ & $\begin{array}{r}32.7 \\
\text { I: } 169.7 \\
\text { II: } 160.8 \\
\text { III: } 133.2\end{array}$ & $\begin{array}{l} \pm \quad 5.5 \\
\pm 41.8 \\
\pm 44.7 \\
\pm 38.2\end{array}$ \\
\hline $\begin{array}{l}\text { Peak velocity }(\mathrm{cm} / \mathrm{s}) \\
\text { Rising slope }(\mathrm{Hz}) \\
\text { Pulsatility index }\end{array}$ & $\begin{array}{l}98.3 \pm 16.6 \\
20.3 \pm 6.2 \\
1.40 \pm 0.23^{* *}\end{array}$ & $\begin{array}{c}107.6 \pm 21.6 \\
22.4 \pm 4.0 \\
1.52 \pm 0.34\end{array}$ & $\begin{array}{c}106.9 \pm 21.6 \\
28.4 \pm 6.1 \\
1.78 \pm 0.33\end{array}$ & $\begin{array}{l}99.7 \\
25.7 \\
1.68\end{array}$ & $\begin{array}{l} \pm 18.8 \\
\pm \quad 5.6 \\
\pm \quad 0.28\end{array}$ \\
\hline \multicolumn{6}{|l|}{ Umbilical artery } \\
\hline Pulsatility index & $1.13 \pm 0.16$ & $0.94 \pm 0.19$ & $0.94 \pm 0.21^{*}$ & $\begin{aligned} \text { I: } & 1.17 \\
\text { II: } & 0.97 \\
\text { III: } & 0.82\end{aligned}$ & $\begin{array}{l} \pm 0.12 \\
\pm 0.19 \\
\pm 0.14\end{array}$ \\
\hline \multicolumn{6}{|l|}{ Umbilical vein } \\
\hline $\begin{array}{l}\text { Mean velocity }(\mathrm{cm} / \mathrm{s}) \\
\text { Volume flow }(\mathrm{ml} / \mathrm{min} / \mathrm{kg})\end{array}$ & $\begin{array}{r}12.6 \pm 3.0 \\
149.9 \pm 39.0^{*}\end{array}$ & $\begin{array}{r}12.8 \pm 4.7 \\
124.1 \pm 51.8\end{array}$ & $\begin{array}{l}12.1 \pm 3.7 \\
86.4 \pm 40.0\end{array}$ & $\begin{array}{r}12.6 \\
\text { I: } 119.7 \\
\text { II: } 103.0 \\
\text { III: } \quad 76.3\end{array}$ & $\begin{array}{l} \pm \quad 3.1 \\
\pm \quad 39.7 \\
\pm \quad 33.6 \\
\pm 24.6\end{array}$ \\
\hline
\end{tabular}

Significance of difference vis-à-vis reference group (unpaired t-test):

* $2 \mathrm{p}<0.05 ; * * 2 \mathrm{p}<0.01$ ).

a For gestational age-dependent variables, separate reference values are given for the three periods of gestation (I, II, III) corresponding to the tests in the diabetic pregnancies.

At test I and II, the distribution of blood flow was the same as in the reference group A. At term, the flow to viscera was $12 \%$ lower in diabetic pregnancies than in the reference group A, that to placenta $5 \%$ higher, and that to lower extremities $7 \%$ higher.

The mean placental weight at term in the diabetic group was 656.1 (SD 175.9) g, which was more than in the reference group $B(p<0.02)$. The umbilical venous blood flow per $100 \mathrm{~g}$ placental weight was 46.6 (SD 13.0) $\mathrm{ml} / \mathrm{min}$, the difference from the value of 50.9 (SD 6.7) $\mathrm{ml} / \mathrm{min}$ in the reference group A being non-significant.

The correlation coefficient between recordings of umbilical venous blood flow, taken within two weeks before parturition, and birth weight was 0.53 (reference value for group A 0.45 ); for placental weight it was 0.81 (reference value for group A 0.83 ). The differences to reference values were statistically non-significant.

White classification: No specific flow variation was observed for any White class. The aortic peak flow velocity in gestational diabetes was higher at test III than in established diabetes $(p<0.05)$.

Maternal diabetic control: No blood flow variable was different in non-optimally regulated diabetes, as compared with well regulated women. There was no over-representing of non-optimally regulated diabetes among women giving birth to largefor-gestational age (LGA) infants. One of the 15 


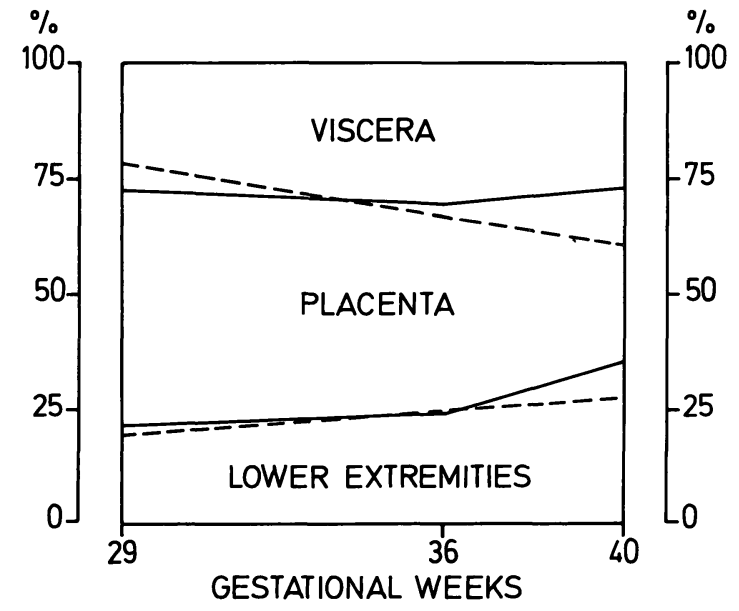

Figure 2. Blood flow distribution in relation to gestational age in the diabetic pregnancies (solid lines) and in the reference group (dashed lines), volume blood flow in the descending thoracic aorta being taken as $100 \%$.

women with abnormally high $\mathrm{HbA}_{1 \mathrm{c}}$ values had gestational diabetes.

Hypertension: No blood flow variable was different in the 11 women with hypertension, as compared with normotensive women. One women on $\beta_{1}$-blocking therapy at the last flow measurement had normal fetal blood flow.

\begin{abstract}
Antenatal electronic FHR monitoring and fetal distress in labor: No difference for any flow variable recorded within three weeks before parturition was found between cases with pathological NSTs ( 7 cases) and those with normal NSTs (26 cases). Similarly, no difference was found between fetuses developing fetal distress in labor (14 cases) and uncompromised fetuses (19 cases).
\end{abstract}

At term (test III), the volume flow in the thoracic descending aorta in cases developing fetal distress was $264.5 \mathrm{ml} / \mathrm{min} / \mathrm{kg}$ (SD $43.1 ; \mathrm{n}=8)$, as compared with $215.7 \mathrm{ml} / \mathrm{min} / \mathrm{kg}$ (SD $41.6 ; \mathrm{n}=14$ ) in uncompromised fetuses $(\mathrm{p}<0.01)$. Corresponding value for the low cord blood $\mathrm{pH}$ group was $273.0 \mathrm{ml} / \mathrm{min} / \mathrm{kg}$ (SD 45.4; $\mathrm{n}=6$ ), and for the normal cord blood $\mathrm{pH}$ group $221.8 \mathrm{ml} / \mathrm{min} / \mathrm{kg}$ $(\mathrm{SD} 41.1 ; \mathrm{n}=14)(\mathrm{p}<0.05)$.

The umbilical artery PI was increased at term in fetuses developing distress in labor (mean 1.04, SD 0.24), as compared with the reference group A $(p<0.01)$. A high PI was found also when comparing for the low cord blood $\mathrm{pH}$ group separately (mean 1.10 , SD $0.26 ; \mathrm{p}<0.01$ ). The fetal aortic volume flow was higher in cases of fetal distress than in the reference group $A(p<0.05)$. A high flow was found also for the low cord blood $\mathrm{pH}$ group $(\mathrm{p}<0.05)$.

Birth weight: The blood flow variables in growth accelerated fetuses (8 LGA) were comparable to normal-weight fetuses except for mean velocity in the umbilical vein at test III, which was increased ( $p<0.05)$. There was no over-representation of LGA infants in any White class or in gestational diabetes, or in the fetuses developing fetal distress in labor. Three of the eight pregnancies resulting in LGA infants were not satisfactorily regulated according to the $\mathrm{HbA}_{1 \mathrm{c}}$ values; the aortic volume flow was high $(>$ mean $+2 \mathrm{SD})$ in two of these three cases.

\section{Discussion}

The results of the present study show that the weight-corrected volume blood flow in the fetal aorta and the umbilical vein was higher in the early third trimester of diabetic pregnancies, as compared with the reference group of normal pregnancies. This is interesting with regard to accelerated fetal growth, which frequently occurs in diabetic pregnancy during this period of gestation [4]. Fetal growth may be influenced more by the total amount of substrate crossing the placenta than by the maternal concentration of different nutrients [7]. At term, the flow decreased to nearnormal values. Conclusions must be drawn from the longitudinal changes with caution, however, as it was not all the same women attending all three tests.

Low vascular resistance might be a contributory factor to a high volume flow. The pulsatility index (PI) is an indicator of vascular resistance distal to the point of measurement [8]. In the early third trimester, the fetal abdominal aortic PI in the diabetic pregnancies was lower than in the reference group, whereas PI in the umbilical artery was equal. This points to a possible low vascular resistance in the lower extremities of fetuses in diabetic pregnancy. Near term, the umbilical artery PI was higher in diabetic than in non-diabetic pregnancies, indicating a higher placental vascular resistance in the former group. The high umbilical artery PI occurred in fetuses who later developed distress in labor. Therefore, a high umbilical artery 
PI cannot be considered characteristic of diabetic pregnancy, although fetal distress in labor might be slightly more common in diabetic pregnancy [21].

The placenta in normal pregnancy proliferates until the 36th gestational week, whereupon its growth ceases [9]. Placental weight, relative to fetal weight and gestational age, is often above normal in diabetic pregnancies [22]. Also in the present study, the placentas were heavier in diabetic than in normal pregnancies. The blood flow distribution to fetal viscera, lower extremities and placenta, was similar to that in normal pregnancy up to 36 weeks. The proportion to placenta increased slightly near term, probably to the detriment of visceral flow. The umbilical volume flow relative to fetal weight was high, whereas the flow relative to placental weight was normal. The correlation coefficients were similar to the reference values.

KIRKINEN \& JouPPILA [13] found abnormally low umbilical venous flow in diabetic women with severe vascular complications and in association with growth retardation. In the present series, no specific blood flow variations were found with regard to White classes. The number of women with vascular complications (White class F; progressive retinopathy and/or nephropathy) was small, however. Not a single case of abnormally low umbilical venous flow was recorded, which might be explained by the fact that no fetus was growth retarded. The fetal circulation was normal also in women with non-optimally regulated diabetes or with hypertension.

Characteristic changes of the aortic blood velocity waveform $[12,14,17]$ and a low umbilical venous flow [11] have been reported as indicators of fetal hypoxia. In the present series, no such flow changes were recorded, suggesting that no case of severe fetal distress occurred antenatally. This is supported by the fact that none of the NSTs was severely pathological.

A high aortic volume flow and high umbilical artery PI was recorded in fetuses developing distress in labor. The high aortic flow might be an expression of an early compensatory mechanism for increased placental vascular resistance, possibly in the form of increased cardiac output. Since fetal distress might be more common in diabetic pregnancy, ultrasonic fetal blood flow measurements are recommended for antenatal fetal surveillance.

\begin{abstract}
Forty pregnant diabetic women were examined with combined Doppler and real-time ultrasound. The volume blood flow in the fetal aorta and umbilical vein was higher and the pulsatility index (PI) in the aorta lower in the early third trimester, as compared with a reference group. Near term, the umbilical artery PI was higher in diabetic than in non-diabetic pregnancies, indicating a higher placental vascular resistance in the former group. The high umbilical artery PI occurred in fetuses who later developed distress in labor. Therefore, a high umbilical artery PI cannot be considered characteristic of diabetic pregnancy, although fetal distress might be more common in diabetic pregnancy. In addi-
\end{abstract}

tion, a high aortic volume flow was found in those fetuses who later develop distress in labor. This might be an expression of an early compensatory mechanism for increased placental vascular resistance. No specific flow variation was observed for any White class, or in association with hypertension or non-optimally regulated diabetes. The blood flow variables in growth-accelerated fetuses were comparable to those found in fetuses with normal weight. Since fetal distress might be more common in diabetic pregnancy, ultrasonic fetal blood flow measurements are recommended for antenatal fetal surveillance.

Keywords: Diabetes, Doppler ultrasound, fetal aortic blood flow, fetal blood circulation, pregnancy, umbilical blood flow.

\section{Zusammenfassung}

\section{Fetaler Flow bei diabetischen Schwangerschaften}

Die kombinierte Doppler- und Real-time Ultraschalltechnik ergibt neue Möglichkeiten, den fetaleǹ Kreislauf $\mathrm{zu}$ untersuchen, was bei Risikoschwangerschaften besonders wertvoll ist. In dieser Hinsicht wurden DiabetesSchwangerschaften nur wenig untersucht. Einige Auto- ren haben einen hohen Blutstrom in der Vena umbilicalis gefunden, andere konnten keine spezifischen Veränderungen bei Diabetes-Schwangerschaften sehen.

In dieser Arbeit wurde der fetale Flow der Vena umbilicalis bei 40 konsekutiven Diabetes-Schwangerschaften mit Hilfe der Doppler- und Real-time-Ultraschalltechnik 
untersucht und mit dem klinischen Bild der Schwangerschaft verglichen.

In die pränatale Überwachung der Diabetes-Schwangerschaften wurde die Bestimmung des $\mathrm{HbA}_{1 \mathrm{C}}$ und die elektronische Registrierung der fetalen Herzfrequenz einbezogen. Während der Geburt wurde die Herzfrequenz elektronisch überwacht und, wenn indiziert, der fetale Blut-pH-Wert bestimmt. Post partum wurde der $\mathrm{pH}$ im Nabelschnurblut gemessen.

Der fetale Blutstrom wurde mit einem $2 \mathrm{MHz}$ gepulsten Doppler-Instrument in Kombination mit einem Realtime-linear-array Scanner zur Gefäßdarstellung gemessen. Die fetale Blutstromgeschwindigkeit wurde in dem mittleren Teil der thorakalen Aorta descendens, in der abdominalen Aorta 1-2 cm oberhalb der Bifurkation, in dem intraabdominalen Teil der Vena umbilicalis und in den Umbilikalarterien registriert. Der Blutstrom wurde nach 26-34 vollendeten Schwangerschaftswochen (Test I), nach 35-37 Wochen (Test II) und zwischen 38 Schwangerschaftswochen und der Geburt (Test III) gemessen. Die Ergebnisse wurden nicht bei der klinischen Führung der Patientinnen berücksichtigt.

21 gesunde Frauen mit unkomplizierten Schwangerschaften bildeten die Referenzgruppe. Diese Frauen wurden im dritten Trimenon jede zweite Woche mit Ultraschall-Doppler-Messungen untersucht.

Im dritten Trimenon ist bei den Diabetes-Schwangerschaften der Blutstrom in der fetalen Aorta bedeutend höher gewesen als in der Referenzgruppe (Tab. II). Dieses war im Test I am deutlichsten, wo auch der „Pulsatility index" (PI) der abdominalen Aorta signifikant niedriger war. Außerdem war im Test I der Blutstrom in der Vena umbilicalis höher als in der Referenzgruppe. In der Arteria umbilicalis war im Test III in der DiabetesGruppe der PI signifikant erhöht.

Die Verteilung des fetalen Blutstromes in den Bauchorganen, unteren Extremitäten und in der Plazenta ist in beiden Gruppen bis zur 36. Schwangerschaftswoche vergleichbar gewesen (Abb. 2). Bei Schwangerschaften am Termin ist der Blutstrom in die Bauchorgane bei Diabetes-Schwangerschaften um $12 \%$ niedriger, in die Plazenta um 5\% höher und in die unteren Extremitäten $7 \%$ höher gewesen als in der Referenzgruppe.

Es gab keine spezifischen Flowvariationen bei den verschiedenen White-Klassen, bei Schwangerschaften mit Hypertension (27,5\% der Schwangerschaften) oder bei
Frauen mit nicht optimal eingestelltem Diabetes (38,5\% der Schwangerschaften). Bei Schwangerschaften am Termin (Test III) war der Blutstrom in der Aorta signifikant erhöht bei Feten, die später eine Asphyxie während der Geburt entwickelt haben. Bei diesen Feten war auch der PI in der Arteria umbilicalis erhöht.

Mit Ausnahme der durchschnittlichen Blutstromgeschwindigkeit der Vena umbilicalis im Test III sind die Blutstromparameter der übergewichtigen Feten mit denen mit normalem Gewicht vergleichbar.

Die Ergebnisse dieser Arbeit zeigen, daß der mit dem Gewicht korrelierte Flow $(\mathrm{ml} / \mathrm{min} / \mathrm{kg})$ in der fetalen Aorta und Vena umbilicalis am Anfang des dritten Trimenon bei den Diabetes-Schwangerschaften höher ist als bei den normalen Schwangerschaften. Das ist interessant im Hinblick auf die akzelerierte fetale Gewichtszunahme, die eher durch die Nutritionszufuhr über die Plazenta als durch die Konzentration verschiedener Nährstoffe im mütterlichen Blut im allgemeinen beeinflußt wird.

Kurz vor der Geburt ist der PI in der Arteria umbilicalis bei diabetischen Schwangerschaften höher als bei normalen, was auf einen höheren plazentaren Gefäßwiderstand in der Diabetes-Gruppe hinweist. Der hohe PI der Arteria umbilicalis kommt bei Feten vor, die während der Geburt eine Asphyxie entwickeln. Deswegen kann ein hoher PI der Arteria umbilicalis nicht als charakteristisch für Diabetes-Schwangerschaften betrachtet werden, auch wenn hier fetale Asphyxien öfter vorkommen. In älteren Publikationen wurde ein abnorm niedriger Flow in der Vena umbilicalis zusammen mit ernsten Gefäßkomplikationen und mit intrauteriner Mangelentwicklung bei Diabetes-Schwangerschaften beschrieben. Ein abnorm niedriger Flow in der Vena umbilicalis konnte in unserer Untersuchung nicht festgestellt werden. Die Erklärung kann sein, daß in unserem Kollektiv keine intrauterinen Mangelentwicklungen vorgekommen sind.

Der hohe Blutstrom in der Aorta bei Feten, die während der Geburt eine Asphyxie entwickeln, kann ein Ausdruck für einen frühen Versuch sein, den erhöhten Gefäßwiderstand in der Plazenta durch ein erhöhtes Herzminutenvolumen zu kompensieren. Weil fetale . Asphyxien öfter bei Diabetes vorkommen können, ist die fetale Flow-Messung bei Diabetes-Schwangerschaften als pränatale Überwachung zu empfehlen.

Schlüsselwörter: Diabetes, Dopplersonographie, fetaler Kreislauf, Flow in der fetalen Aorta, Schwangerschaft, umbilikaler Flow.

\section{Résumé}

Débits sanguins fœetaux au cours de la grossesse chez les diabétiques

La technique combinée du Doppler et du temps réel en échographie permet des nouvelles possibilités d'examen de la circulation fotale, ce qui peut être important, spécialement pour les grossesses comportant un grand risque. Pour les grossesses chez les diabétiques, les rap-

ports sur ce sujet sont cependant rares. Certains auteurs ont trouvé un débit sanguin élevé dans la veine ombilicale, tandis que d'autres ont omis de démontrer quelques anomalies spécifiques des grossesses diabétiques.

La présente étude faite successivement sur $\mathbf{4 0}$ femmes diabétiques enceintes a été entreprise pour vérifier s'il existait quelques relation entre le débit sanguin fœtal, 
déterminé par Doppler et l'échographie en temps réel et les variations cliniques dans les grossesses diabétiques. La surveillance prénatale des grossesses diabétiques comprend les déterminations de $\mathrm{l}^{\prime} \mathrm{HbA}_{\mathrm{ic}}$ et la surveillance électronique du rythme cardiaque fœtal (RCF: rythme cardiaque fotal). Pendant le travail, le RCF est mesuré électroniquement et on détermine aussi le $\mathrm{pH} d u$ sang au scalp lorsqu'il y a une indication. Le $\mathrm{pH}$ au sang du cordon ombilical est déterminé à la naissance. On mesure le débit sanguin fœtal au moyen d'une sonde Doppler de fréquence de $2 \mathrm{MHz}$ combinée à une échographie linéaire. La vitesse du sang fœtal est enregistrée dans la partie moyenne de l'aorte thoracique descendante, dans l'aorte abdominale, 1 à $2 \mathrm{~cm}$ au-dessus de la bifurcation, dans la partie intra-abdominale de la veine ombilicale et dans les artères ombilicales au niveau du cordon.

On a mesuré le débit sanguin de $26-34$ semaines (test I), à 35-37 semaines (test II) et entre 38 semaines et l'accouchement (test III). Les résultats n'ont pas été utilisés pour des conseils cliniques.

Comme groupe de référence, on a choisi un groupe de 21 femmes en bonne santé avec des grossesses sans complications. Ces femmes ont été examinées par des mesures Doppler tous les quinze jours durant le troisième trimestre.

On a trouvé que le débit sanguin dans l'aorte fotale tout au long du troisième trimestre, était toujours plus élevé chez les grossesses diabétiques que dans le groupe de référence (tableau II). Ceci était le plus marqué au test I, quand l'index de pulsation ( $\mathrm{PI}=$ pulsatility index) dans l'aorte abdominale était manifestement inférieur. De plus, au test I, le courant sanguin dans la veine ombilicale était plus élevé que dans le groupe de référence. Dans l'artère ombilicale, au test III, le PI était élevé de façon significative dans le groupe diabétique.

La distribution du débit sanguin fœtal aux viscères, aux extrémités inférieures et au placenta était similaire dans les deux groupes jusqu'à la 36ème semaine (figure 2). A terme, dans les grossesses diabétiques, le débit aux viscères était de 12 p.c. moins élevé que dans le groupe de référence, et le débit était de 5 p.c. plus élevé dans le placenta, et de 7 p.c. plus élevé aux extrémités inférieures.

On n'a observé aucune variation spécifique de débit dans aucune "classe de White», dans les grossesses compliquées d'hypertension (27,5 p.c. des grossesses), ou chez les femme ayant un diabète traité de façon non optimale (38,5 p.c. des grossesses). A terme (test III), le courant sanguin dans l'aorte était augmenté de façon significative chez les fœtus en risque d'asphyxie pendant le travail, comparé aux fœtus non compromis. En outre, le PI de l'artère ombilicale était augmenté de façon significative chez les fotus en risque d'asphyxie pendant le travail.

Avec comme exception la vitesse moyenne dans la veine ombilicale au test III, les paramètres du courant sanguin chez les fœtus de croissance accélérée, étaient comparables à ceux des fotus de poids normal.

Les résultats de cette étude montrent que le débit sanguin dans l'aorte foetale et la veine ombilicale corrigé d'après le poids, est plus élevé au début du troisième trimestre des grossesses diabétiques, comparé au groupe de référence des grossesses normales.

Ceci est intéressant en ce qui concerne l'accélération de croissance du fœetus, qui peut être influencée plus par la quantité totale de substances traversant le placenta que par la concentration maternelle des différents ingrédients nutritifs.

Près du terme, le PI de l'artère ombilicale était plus élevé dans les grossesses diabétiques que dans les grossesses normales, indiquant une plus grande résistance vasculaire placentaire dans le groupe diabétique. Le PI élevé dans l'artère ombilicale se recontre chez les fotus qui plus tard sont en risque d'asphyxie durant le travail. Par conséquence, un PI élevé dans l'artère ombilicale ne peut pas être condidéré comme caractéristique de grossesse diabétique, bien que le risque d'asphyxie fotale puisse être plus courant dans celle-ci. Des auteurs précédents ont trouvé un courant sanguin anormalement bas dans la veine ombilicale chez les femmes diabétiques avec des complications vasculaires sévères et en associant avec un retard de croissance. Dans les séries présentes, on n'a pas enregistré un seul cas de débit sanguin anormalement bas dans la veine ombilicale, ce qui peut être expliqué par le fait que le croissance d'aucun fotus n'était retardée. Le débit élevé dans l'aorte chez les fotus présentant un risque d'asphyxie durant le travail peut être l'expression d'un mécanisme de compensation précoce pour une plus grande résistance vasculaire placentaire, probablement sous forme d'augmentation du débit cardiaque. Puisque le risque d'asphyxie fotale peut être plus courant dans la grossesse diabétique, les mesures par ultrason du débit sanguin fotal sont recommendées pour la surveillance fœtale prénatale.

Mots-clés: Circulation sanguine fœtale, débit sanguin ombilical, débit sanguin aortique fœtal, diabète, échographie Doppler, grossesse.

Acknowledgements: The expert help in performing the fetal blood flow measurements by Miss LENA BERG and Mrs. ANN THURING-JöNsSON, and the help in collecting clinical data by Dr. GöRAN EKBERG is gratefully acknowledged. The study was supported by grants from the Swedisch Medical Research Council (no. 05980 and 07498) and the First of May Flower Campaign for Children's Health. 


\section{References}

[1] Beard RW, GM Filshie, CA KNight, GM RoBERTS: The significance of the changes in the continuous fetal heart rate in the first stage of labour. J Obstet Gynaecol Br Commonw 78 (1971) 865

[2] Eik-Nes SH, AO BrubaKk, M UlsteIn: Measurement of human fetal blood flow. Br Med J 1 (1980) 283

[3] Eik-Nes SH, K Marsál, K Kristoffersen: Methodology and basic problems related to blood flow studies in the human fetus. Ultrasound Med Biol 10 (1984) 329

[4] GeLlis SS, DY-Y Hsia: The infant of the diabetic mother. Am J Dis Child 97 (1959) 1

[5] GILl RW, G Kossoff: Pulsed Doppler combined with B-mode imaging for blood flow measurement. Contrib Gynecol Obstet 6 (1979) 139

[6] Gill RW, G Kossoff, BJ TRUdinger, PS WARREN: Flow velocity in the venous return from the placenta. In: KURJAK A: Recent advances in ultrasound diagnosis 2, pp 229. Excerpta Medica, Amsterdam 1980

[7] Gillmer MDG, RW Beard, NW OAKLey, FM BROOKE, MC ElPHICK, D. Hull: Diurnal plasma free fatty acid profiles in normal and diabetic pregnancies. Br Med J 2 (1977) 670

[8] Gosling RG, G Dunbar, DH King, DL Newman, CD SIOG, JP WOODCOCK, DE FITZGERALD, JS KEATES, D MACMILLAN: The quantitative analysis of occlusive peripheral arterial disease by a non-invasive ultrasonic technique. Angiology 22 (1971) 52

[9] Gruenwald P: Chronic fetal distress and placental insufficiency. Biol Neonate 5 (1963) 215

[10] Ingemarsson E, I Ingemarsson, T Solum, M WESTGREN: A one-year study of routine fetal heart rate monitoring during the first stage of labor. Acta Obstet Gynecol Scand 59 (1980) 297

[11] JoupPILA P, P KIRKINEN: Umbilical vein blood flow as an indicator of fetal hypoxia. Br J Obstet Gynaecol 91 (1984) 107

[12] JOUPPILA P, P KIRKINEN: Increased vascular resistance in the descending aorta of the human fetus in hypoxia. Br J Obstet Gynaecol 91 (1984) 853

[13] KIRKINEN P, P JoupPILA: Ultrasonic measurement of human umbilical circulation in various pregnancy complications. In: SANDERS RC, M HILL: Ultrasound Annual, pp 153. Raven Press, New York 1983
[14] Lingman G, J Laurin, K Marsál: Aortic blood flow in normal and growth retarded fetuses $(\mathrm{Ab}$ stract). In: GeNNSER G, K MARSÁL: Xth Conference on Fetal Breathing and Other Fetal Measurements, p 79. Malmö 1983

[15] Lingman G, K Marsál: Fetal central blood circulation in the third trimester of normal pregnancy. A longitudinal study. I. Aortic and umbilical blood flow. Early Hum Dev 13 (1986) 137

[16] Lingman G, K Marsál: Fetal central blood circulation in the third trimester of normal pregnancy. A longitudinal study. II. Aortic blood velocity waveform. Early Hum Dev 13 (1986) 151

[17] Lingman G, J LaURIN, K Marsál: Circulatory changes in fetuses with imminent asphyxia. Biol Neonate 49 (1986) 66

[18] McCallum WD, CS Williams, S Napel, RE DaiGLE: Fetal blood velocity waveform. Am J Obstet Gynecol 127 (1978) 491

[19] Montan S, P Olofsson, T Solum: Classification of the nonstress test and fetal outcome in 1,056 pregnancies. Acta Obstet Gynecol Scand 64 (1986) 639

[20] OlofsSON P, H LIEDHOLM, G SARTOR, N-O SJÖBERG, NW SVENNINGSEN, D URSING: Diabetes and pregnancy. A 21-year Swedish material. Acta Obstet Gynecol Scand [Suppl] 122 (1984) 1

[21] Olofsson P, I Ingemarsson, T Solum: Fetal distress during labour in diabetic pregnancy. $\mathrm{Br} \mathrm{J}$ Obstet Gynaecol 93 (1986) 1067

[22] Pedersen J: The Pregnant Diabetic and Her Newborn. 2nd ed. Munksgaard, Copenhagen 1977

[23] Persson PH, BM Weldner: Intrauterine weight curves obtained by ultrasound. Acta Obstet Gynecol Scand 65 (1986) 129

[24] STERKY G: Swedish standard curves for intra-uterine growth. Pediatrics 46 (1970) 7

[25] Visser GHA, RN LAuRINI, W JAGER, M DE SMEDT, EJ МеҮвоом: Umbilical artery velocity waveforms in type-1-diabetic pregnancy; a longitudinal study (Abstract C-23). XII Annual Meeting of the Society for the Study of Fetal Physiology. Haifa 1985

Received December 13, 1986. Revised May 11, 1987. Accepted June 9, 1987.

Per Olofsson, M. D.

Department of Obstetrics and Gynecology

University Hospital

S-221 85 Lund, Sweden 


\section{Schneider · Stroinski}

\section{Comprehensive $B_{12}$}

\section{Chemistry · Biochemistry · Nutrition Ecology $\cdot$ Medicine}

1987. $18 \mathrm{~cm} \times 26 \mathrm{~cm}$. XII, 409 pages, numerous illustrations.

Hardcover. DM 290,-; approx. US \$160.00

ISBN $311008239 \mathrm{X}$

This book is addressed to clinicians and advanced students in different areas such as chemists, biochemists, pharmacologists, nutritionists, animal breeders, ecologists and marine biologists who wish to extract essential information on particular aspects of vitamin $B_{12}$.

Most of the data presented are accompanied by references to the original literature and are preceded by a brief and comprehensive introduction.

Some techniques which at present are of interest to a wider group of researchers such as immobilization of vitamin $B_{12}$ on supports, methods of $B_{12}$ assay and biological or chemical synthesis of various $B_{12}$ analogues are described in detail.

\section{Contents in brief}

Historical outline - Nomenclature of Corrinoids - Chemistry of Cobalamin and Related Compounds - Biosynthesis of Vitamin $B_{12}$. Purification and Estimation of Vitamin $B_{12}$. The Occurrence and Distribution of Corrinoids - Cobamide Dependent Enzymes · Non-Enzymatic Vitamin $B_{12}$ Binding Proteins in Man and Animals - Medical Aspects of Vitamin $B_{12} \cdot$ Index of Species - Subject Index

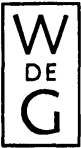

\section{de Gruyter - Berlin · New York}

